\title{
Deposit Money Bank Policy and Private Sector Funding: A Multi-Dimensional Study from Nigeria
}

\author{
Zaagha Alexander Sulaiman \\ Department of Banking and Finance \\ Rivers State University, Port Harcourt, Nigeria \\ E-mail: zaaghi75@gmail.com \\ Murray Monday Ebike \\ Department of Banking and Finance \\ Rivers State University, Port Harcourt, Nigeria \\ E-mail: fathermurraye@gmail.com
}

\begin{abstract}
This study empirically examined the effect of deposit money banks policy on private sector funding in Nigeria. Time series data was sourced from Central Bank of Nigeria Statistical Bulletin from 1985-2018. Credit to private sector, credit to core private sector and credit to small and medium scale enterprises was used as dependent variables while liquidity ratio and loan to deposit ratio was used as independent variables. Ordinary Least Square (OLS), Augmented Dickey Fuller Test, Johansen Co-integration test, normalized co-integrating equations, parsimonious vector error correction model and pair-wise causality tests were used to conduct the investigations and analysis. The empirical findings revealed that deposit money banks policy explains 40.8 percent variation on credit to core private sector, 28 .I percent and 58.9 percent of the variation in credit to core private sector and credit to small and medium scale enterprises sector. The study conclude that deposit money banks policy has no significant relationship with credit to private sector and credit to core private sector but has significant relation with credit to small and medium scale enterprises sector. From the findings, the study recommends compliance to deposit money banks policies; this will enhance effective financial intermediation and increase funding of the private sector. There is also need for the regulatory authorities to harmonize the various deposit money banks policies with the objective of enhancing private sector funding. There is need to decentralize the operation of the deposit money banks in the urban cities. Policies should be formulated to extend the operation of the deposit money banks to the rural communities, this will enable the institutions to mobilize much deposit and increase credit to the private sector.
\end{abstract}

Keywords: Deposit Money Banks Policy, Private Sector Funding, Liquidity Ratio, Loan to Deposit Ratio, Small and Medium Scale Enterprises

\section{Introduction}

The history of banking in Nigeria dates back tol892 when African Banking Corporation and bank of British West Africa now first bank was established. This means that banking business has existed for over one century in Nigeria (Olukayode and Somoye, 2018). Deposit money banks are empowered by law to undertake the business of lending and borrowing in the economy, the function bridge the savings and investment gap. This responsibility evolved over time and expanded to include investment management, maintenance of payments system, trade transactions, cards and e-payments.

Banking activities are guided by policies directed toward achieving economic goals and enhance stability of the institutions. Liquidity policy gives information about the general liquidity shock absorption capacity of a bank. As a general rule, the higher the share of liquid assets in total assets, the higher the capacity to absorb liquidity shock. High value of this ratio can be interpreted as inefficiency, since liquid assets yield lower income liquidity bears high opportunity costs for the bank (Ogolo, 2018). Increase on liquidity reserve reduces the earnings assets of commercial banks. This implies that increase liquidity policy can affect negatively deposit money banks credit to the private sector.

Private sector actors are increasingly being recognized as a major driving force in enhancing economic growth and development. They drive economic growth through investment, employment and business creation, innovation and knowledge transfer, and other multiplier effects from their operations and activities. Ensuring that this growth is likely to contribute to long-term poverty reduction, however, requires private companies to include the poor as producers, suppliers, employees and consumers. Under the right circumstances, public-private partnerships that are based on the identification of complementary expertise and shared commercial and development interests are also an important tool that can harness the private sector's contribution to such 
inclusive growth. While the importance of the private sector to economic growth has long been recognized, until very recently, private sector actors were not seen as development actors. As a result, they were typically treated as a secondary consideration in terms of potential vehicles of development financing and in terms of sources of ideas and input in development debates and policies, in comparison with the primary and more established group of actors: recipient governments and bilateral and multilateral development agencies (Eke, Chikulirim Eke and Inyang, 20I5).

Liquidity policy is more focused on bank's sensitivity to selected types of funding such as deposits of households, enterprises and other financial institutions. It captures bank's vulnerability related to these funding sources. Banks are able to meet its obligations in terms of funding if volume of liquid assets is high enough to cover volatile funding and if the value of this ratio is IO0 percent or more. Lower value indicates a bank's increased sensitivity related to deposit withdrawals.

Loan-to-deposit ratio policy was introduced for the purposes of curbing the incentives for excessive competition among domestic banks dependent upon wholesale funding to increase their business sizes before the global financial crisis, and improving liquidity conditions during crises (Lopez-Espinosa, Moreno, Rubia and Valderrama, 2012). Loan-deposit ratio policy is effective as a macro prudential policy instrument; it reduces banks' dependency on wholesale funding to thereby curb the interconnectedness among financial institutions, a systemic risk on the cross-sectional side, and also reduces the procyclicality of lending, a systemic risk on the time-series side. The policy is not only useful but also actually brings about ringfencing between retail and wholesale financing by encouraging banks to extend loans within the limits of their deposits. Bank loans shows pro-cyclicality in terms of the amounts of their supply and demand. During times of economic expansion, when loan demand is extremely high, a bank's capability to mobilize funding in response to this need is a key factor determining the pro-cyclicality of its loans.

Deregulation of financial sector in the last quarter of 1986 resulted in wide disparities in monetary policy targets with possible implications for commercial bank lending operations. Most studies focus on the effect of interest rate on economic growth (Oshikoya, 1992; Odhiambo, 2010) or on bank lending separately during regulation or deregulation periods (Amassoma et al. 20II; Nwakama and Mbatogu, 2004; Owolabi, 20I4). Others investigated the relationship between monetary policy instruments and Deposit Money Banks Loans and Advances (Ogolo, 2018 and Adeniyi et al. 2018) and the determinant and evidence of the impact of liquidity management on the performance of deposit money banks (Dhanuskodi, 20I4; Alphonce, Silvanos, and Ziska, 52015; Daniel, 2017). While literature on the effect of interest rate on the economy and impact of LDR and bank liquidity on DMBs profitability is well documented in literature, the effect of deposit money banks policy on private sector funding is lacking. This study empirically examined the effect of deposit money banks policy on private sector funding in Nigeria.

\section{Literature Review}

\section{Loan to Deposit Ratio}

The loan-to-deposit ratio regulation was introduced for the purposes of curbing the incentives for excessive competition among domestic banks dependent upon wholesale funding to increase their business sizes before the global financial crisis, and improving liquidity conditions during crises (Lopez-Espinosa, Moreno, Rubia and Valderrama, 2012). According to Dhanuskodi (2014), loan to deposit ratio is a useful instrument to determine bank liquidity, and by extension, it influences the profitability of banks. The regulation of loan to deposit ratio is basically an instrument for effective management of banks liquidity by limiting their loan size within the certain ratio of their deposits. During a period of economic expansion, however, this regulation is used to curb any expansion in lending (CGFS, 2012).

As part of its monetary policy effort towards ensuring that DMBs increase its financial intermediation function, stem financial inclusion and increase lending to the real sector of the Nigerian economy, the CBN increase the loan to deposit ratio to 60 percent. The apex bank in a bid to ensure compliance opine that banks that fail to meet the deadline of March ending 2019 will attract 50 percent levy of additional CRR of the lending shortfall of the target LTDR. The LTDR was further increase to 65 percent in the last quarter of 2019 to facilitate robust investment and disbursement of credit to the real sector of the Nigerian economy that will bring about a sound and resilient financial intermediation system.

Since the introduction of the loan to deposit ratio policy, the effects that the regulatory authorities intended have found banks' wholesale funding on the decline and liquidity conditions have improved. Empirical analysis shows that the loan-to-deposit ratio regulation is also effective as a macro prudential policy instrument; it reduces banks' dependency on wholesale funding to thereby curb the interconnectedness among financial institutions, a systemic risk on the cross-sectional side, and also reduces the pro-cyclicality of lending, a systemic risk on the time-series side. It should be noted, however, that the loan-to-deposit ratio regulation is a strong but not precise policy instrument that directly limits the ratio of deposits DMBs to loans, two core 
business areas of banks, and may overlap with the Basel III liquidity regulations. In addition, the regulatory authorities and the central bank need to work in close cooperation when making changes in policies regarding this regulation, given that the loan-todeposit ratio regulation can affect banks' intermediary role and the channels of monetary policy transmission (Bouvatier, LópezVillavicencio and Mignon, 2010).

The loan-to-deposit ratio regulation is a macro prudential policy instrument designed to curb systemic risks. The regulation is not only useful but also actually brings about ring-fencing between retail and wholesale financing by encouraging banks to extend loans within the limits of their deposits. Given however that this regulation is a powerful monetary policy tool, that puts direct constraints on banks' core businesses of deposits and loans, some unintended consequences could be created.

Bank loans shows pro-cyclicality in terms of the amounts of their supply and demand. In particular, during times of economic expansion, when loan demand is extremely high, a bank's capability to mobilize funding in response to this need is a key factor determining the pro-cyclicality of its loans. The reason why Nigeria domestic banks were able to meet the heightened demand for loans in the run up to the global financial crisis was that, in addition to deposits, they were capable of mobilizing funds to meet this demand through wholesale funding. Since introduction of the loan-to-deposit ratio regulation, banks have moved funds out of their wholesale funding CDs and into corporate deposits to be able to comply with the regulation (Berger and Udell, 2004).

Loan-to-deposit ratio regulation could affect banks' function of financial intermediation by hindering their flexible use of wholesale funding as assets for bank lending. Facing restraints on their assets for lending, banks generally tend to first reduce their lending to SMEs whose credit ratings are relatively low. According to Jeong, (2009) bank lending to large corporations and households has continued to rise since introduction of the loan-to-deposit ratio regulation, whereas their lending to SMEs has stagnated or declined.

\section{Bank Liquidity Ratio}

Bank for International Settlements (2008) defined liquidity as the ability of bank to fund increases in assets and meet obligations as they come due, without incurring unacceptable losses. Liquidity risk arises from the fundamental role of banks in the maturity transformation of short-term deposits into long-term loans. The term liquidity risk includes two types of risk: funding liquidity risk and market liquidity risk. Funding liquidity risk is the risk that the bank will not be able to meet efficiently both expected and unexpected current and future cash flow and collateral needs without affecting either daily operations or the financial condition of the firm. Market liquidity risk is the risk that a bank cannot easily offset or eliminate a position at the market price because of inadequate market depth or market disruption. Liquidity risk can be measured by two main methods: liquidity gap and liquidity ratios. The liquidity gap is the difference between assets and liabilities at both present and future dates.

Positive gap between assets and liabilities is equivalent to a deficit (Bessis, 2009). Liquidity ratios are various balance sheet ratios which should identify main liquidity trends. These ratios reflect the fact that bank should be sure that appropriate, low-cost funding is available in a short time. This might involve holding a portfolio of assets than can be easily sold (cash reserves, minimum required reserves or government securities), holding significant volumes of stable liabilities (especially deposits from retail depositors) or maintaining credit lines with other financial institutions. Various authors like More (2010); Praet (2009); Rychtárik (2009) provide various liquidity ratios. Bank liquidity can be measured as follows:

\section{$\underline{\text { Liquid assets }}$}

Total assets

The liquidity ratio should give us information about the general liquidity shock absorption capacity of a bank. As a general rule, the higher the share of liquid assets in total assets, the higher the capacity to absorb liquidity shock, given that market liquidity is the same for all banks in the sample. Nevertheless, high value of this ratio may be also interpreted as inefficiency, since liquid assets yield lower income liquidity bears high opportunity costs for the bank. Thus it is necessary to optimize the relation between liquidity and profitability.

$\underline{\text { Liquid assets }}$

Deposits + short term borrowing

The liquidity ratio is more focused on the bank's sensitivity to selected types of funding (we included deposits of households, enterprises and other financial institutions). The ratio should therefore capture the bank's vulnerability related to these funding sources. The bank is able to meet its obligations in terms of funding (the volume of liquid assets is high enough to cover volatile 
funding) if the value of this ratio is $100 \%$ or more. Lower value indicates a bank's increased sensitivity related to deposit withdrawals.

$\underline{\text { Loans }}$

Total assets

The ratio measures the share of loans in total assets. It indicates what percentage of the assets of the bank is tied up in illiquid loans. Therefore, the higher this ratio the less liquid the bank is.

$\underline{\text { Loans }}$

Deposits + short term borrowing

The last liquidity ratio relates illiquid assets with liquid liabilities. Its interpretation is the same as in case of ratio the higher this ratio the less liquid the bank is. Although liquidity problems of some banks during global financial crisis re-emphasized the fact that liquidity is very important for functioning of financial markets and the banking sector, an important gap still exists in the empirical literature about liquidity and its measuring.

\section{Private Sector Funding}

The private sector is said to be the engine of economic growth for a country, especially, for developing economies (William, Zehou and Hazimi, 2019). The private sector remains the nucleus that drives economic growth. Private sector funding (credit) is no doubt a driver of the real economy, particularly in developing economies like Nigeria where the financial markets are porous and near well developed to mobilize the needed resources to accelerate the desired level of economic development. The private sector is the part of the economy that is run by individuals and companies for profit and is not state controlled. Therefore, it encompasses all for-profit businesses that are not owned or operated by the government. According to the global economic report (2019), domestic credit to private sector by banks refers to financial resources provided to the private sector by other depository corporations (deposit taking corporations except central banks), such as through loans, purchases of non-equity securities, and trade credits and other accounts receivable, that establish a claim for repayment. It involves the pros and cons through which individuals and statutory firms' gains access to the availability of credit (fund) to finance and promote (drive) investment. Private sector funding involves credit extended by the banking and financial institutions to the private sector of the economy alone and basically include firms and households excluding loans disbursed to the public sector.

Credit to private sector by banks refers to financial resources provided to the private sector by other depository corporations (deposit taking corporations except central banks), such as through loans, purchases of non-equity securities, and trade credits and other accounts receivable, that establish a claim for repayment. Credit to the core private sector refers to credit from the commercial banks and other credit institutions to the preferred sectors of the economy. This is measured as annual loans and advances from credit institutions in Nigeria to the real sectors of the economy. This study adopts the total credit disbursement to the core private sector as a measure through which monetary policy affects private sector funding in the Nigerian economy.

\section{Funding Small and Medium Scale Enterprises Sector in Nigeria}

In Nigeria, the national policy on micro, small and medium enterprises define small and medium scale enterprises along the lines of international criteria. The policy mainly uses the employment base and asset size to categorize firms into micro, small and medium. Accordingly, for small-scale enterprises, the employment base should be between I0 and 49 with an asset base of over N5 million but less than N50 million. Medium scale enterprises are those that employ between 50 and I99 workers, with an asset base of over N50 million but less than N500 million. Importantly, the assets admitted for these classifications exclude land and buildings. Also, in case of conflict of classification between employment and asset size, the policy gives pre-eminence to the number of employees over asset size. Bank credit refers to loans, advances and discounts of specific sums, which are normally with terms and other conditions available to individuals, small and medium sized business to start, grow or sustain any economic activity (John and Onwubiko, 2013).

Credit to small and medium scale enterprises sector refers to credit disbursed to small and medium scale enterprises by the deposit money banks. It is measured as annual loans and advances from the financial institutions in Nigeria to small and medium scale enterprises. The central bank of Nigeria statistical bulletin reports credit to small and medium scale enterprises as percentage of total credits in the economy.

\section{Theoretical Review}

\section{The Loanable Funds Theory}

The neo-classical or the loanable fund theory examines interest rate in terms of demand and supply of loanble funds or credit. According to this theory, the rate of interest is the price of credit which is determined by the demand and supply for lonable 
funds. In the words of Prof Lerner in Jhingan (2005); it is the price which equates the supply of credit, or saving plus the net increase in the amount of money in a period, to the demand for credit, or investment plus net hoarding in the period. The demand for loanble fund has primarily three source; government, businessmen and consumers who need them for purpose of investment, hoarding and consumption. The government borrows funds for constructing public works or for war preparations. The businessmen borrow for the purpose of capital goods and for starting investment projects. Such borrowings are interest elastic and depend mostly on the expected rate of profit as compared with the interest rates. The demand of loanable fund on the part of consumers is for the purchase of durable consumer goods like cars, houses etc. Individual borrowings are also interest elastic. The tendency to borrow is more at a lower rate of interest than at a higher rate.

Loanable funds theory of interest rate determination views the level of interest in the financial market as resulting from the factors that affect the supply and demand of loanable funds (Saunders 20I0).Interest rate in this theory is determined just like the demand and supply of goods is determined, supply of loanable funds increases as interest rate increases, other factors held constant. He goes further to explain that the demand for loanable funds is higher as interest rate fall, other factors held constant. Saunders (2010) identifies two factors among others causing demand curve for loanable funds to shift; economic conditions and the monetary expansion refers to the sum of money offered for lending and demanded by consumers and investors during a given period. The interest rate model is determined by the interaction between potential borrowers and potential savers.

\section{Credit Rationing Theory}

Access to credit is explained by credit rationing theory (Stiglitz and Weiss, I98I; Bester, I985; Cressy, I996; Baltensperger and Devinney, 1985). According to Stiglitz and Weiss (I98I) credit rationing is said to occur when some borrowers receive a loan, while others do not. Credit rationing takes place at either financier level due to loan markets imperfection and information asymmetry or voluntarily by the borrowers (voluntary exclusion). At financier level, credit rationing occurs in a situation where demand for credit exceeds supply at the prevailing interest rate (Stiglitz and Weiss, I98I). There is scant literature on selfrationing, however, in situations where credit rationing is voluntary, Arora (2014) described such borrowers as non-credit seekers due to personal, culture or social reasons or could be in the bracket of discouraged borrowers. Bester (I985) suggested that financiers may choose to reject some borrowers because of negative enticement effects. For example, for given collateral, an increase in the rate of interest causes adverse selection, since only borrowers with riskier investments will apply for a loan at a higher interest rate. Similarly, higher interest payments create an incentive for investors to choose projects with a higher probability of bankruptcy (Afonso and Aubyn, 1997, 1998; Matthews and Thompson, 2014). On the other hand, for a fixed rate of interest, an increase in collateral requirements may also result in a decline in the lender's profits (Cressy, I996). Stiglitz and Weiss (198I) showed that this happens if the more risk-averse borrowers, those that choose relatively safe investment projects, drop out of the market. According to Bester (1985) Andretti (I983), if financiers set collateral requirements and the rate of interest to screen investors' riskiness, then no credit rationing will occur at equilibrium. This is because increasing collateral requirements tends to result in adverse selection, even with risk-neutral investors (Bester, I984a, 1985).

\section{Empirical Review}

Ajayi and Atanda (2012) investigated the impact of monetary policy instruments on banks performance between I980 and 2008. The study used Engle-granger two-step co-integration approach for its analysis. The result indicated that bank rate, inflation rate and exchange rate are credit enhancing variables, while liquidity ratio and cash reserves ratio exert negative impact on banks total credit. Although, it is only cash reserve ratio and exchange rate that are found to be significant at $5 \%$ critical value. The study found that monetary policy instruments are not significant to stimulate credit in the long-run, while banks total credit is more responsive to cash reserve ratio.

Nto, Mbanasor and Osuala (2012) examined the influence of monetary policy variables on banks' credit supply to SMEs in Nigeria. Time series data were collected on quarterly basis covering a period of 1995-20I0 and were analyzed using Fully Modified Least Squares (FMOLS). The results indicated that policies on interest rate and liquidity ratio were negatively and positively significant to SMEs. The study recommends that government through CBN should strengthen existing policies on the monetary policy instruments so as to increase and stabilize credit supply to SMEs.

Dhanuskodi (2014) examines the impact of Loan Deposit ratio on the profitability of Malaysian commercial banks for the period of 2009 to 2013 using all the 8 locally owned commercial banks in Malaysia. The study use loan deposit ratio of the banks as the independent variable and the dependent variable was profitability which measures through Return on Assets (ROA). Data were sourced mainly from the annual reports of the 8 banks. Ratio analysis along with descriptive, correlation analysis, paired $\mathrm{T}$ - test and regression analysis were used in the study. The result of the study indicated that there was a positive and non-significant impact of LDR on ROA in five banks (Bank I, 2, 3, 4 and 8). Further, the study revealed that only one bank (Bank 5) had a negative and non-significant impact of LDR on ROA and bank 7 had positive and significant impact. 
Hyunggeun, Hyunwoo and Dokyung (2015) conduct an empirical analysis of the usefulness of the loan-to-deposit ratio using panel data regression model. The results of cross-sectional analysis indicate that as a bank's share of wholesale funding declines, the indicator $(\Delta \mathrm{CoVaR}$ value) of interconnectedness among financial institutions is reduced. Findings show that loan-to-deposit ratio regulation has served as an effective macro-prudential policy tool by weakening the interconnectedness among financial institutions and the pro-cyclicality of bank lending. Analysis of the loan-to-deposit ratio regulation's effects on the monetary policy transmission channels suggests that, among the various transmission channels, the loan-to-deposit ratio influences the effectiveness of the bank lending channel, by changing bank conditions for asset management and funding. This implies that the supervisory authorities and the central bank, which are in charge of the loan-to-deposit ratio regulation, need to maintain a closer cooperative relationship.

Alphonce, Silvanos and Ziska (2015) study was to find out the relationship between liquid assets and profitability of commercial banks in Zimbabwe. A quantitative correlation approach was adopted for the study in which testable hypotheses were formulated based on literature review findings. Eight years historical financial statements data relating to two periods; 2005 to 2008 and 2009 to 2012 was collected from selected commercial banks in Zimbabwe. The study found that working capital was weakly related to profitability, while capitalization strongly influenced commercial bank profitability. An inverse relationship was found between the ratio of loans to deposits and commercial bank profitability. It was therefore concluded that the composition of current assets strongly influences commercial bank profitability. This study recommends that RBZ should monitor the capitalization levels of commercial banks and create policies to ensure growth and commercial banks should monitor the structure or composition of current assets in order to ensure profitability.

Anigbogu, Okoli and Nwakoby (2015) investigated the effect of financial intermediation on small and medium enterprises performance in Nigeria between 1980-2013 using an econometric model of the Ordinary Least Square (OLS). Findings revealed that with the exception of bank interest rate to SMEs, all other variables namely bank lending rate to SMEs, exchange rate and monetary policy have a positive and significant influence on small and medium enterprises performance in Nigeria.

Ovat (2016) examined the role played by commercial banks' credit in facilitating the growth of SMEs in Nigeria. The study adopted co-integration and error correction mechanisms and based on the findings, exchange rate and lending rate are statistically significant to SMEs credit. Also, inflation rate was found to be significant but negative to SMEs credit. He opined that SMEs should be made to have easy access to credits from commercial banks. In order to achieve this, the monetary authority should ensure that the lending rate at which commercial banks lend to the SMEs is reduced to the barest minimum. More so, devaluation of the national currency should not be encouraged as devaluation makes the cost of imported raw materials and capital goods used by the SMEs very expensive and hence impedes their production, rather local sourcing of raw materials should be encouraged to reduce the pressure on exchange rate.

D'Pola, and Touk, (2016) empirically examine the impact of commercial bank credit on the performance of Small and Medium Size Enterprises (SMEs) in Cameroon between 1980 and 2014 using Ordinary Least Square (OLS) method to estimate the multiple regression model. The study use SMEs output as approximated by wholesale and retail trade output as a component of the GDP. The results revealed that commercial bank credit and real interest rate have a negative and significant impact on the performance of SMEs in Cameroon.

Sesay and Abdulai (2017) empirically investigate monetary policy effects on private sector investment in Sierra Leone. The study examines the rate at which changes in monetary policy in Sierra Leone has affected the behavior of private sector investments, theories and empirical studies are reviewed in a way to identify a suitable model for private sector investment for the period I980-20I4 using recent econometric techniques (OLS, VECM, VAR). Results of the findings suggest that money supply and gross domestic saving exert positive and statistically significant effect on private sector investments whereas Treasury bill rate, inflation and gross domestic debt exert a negative effect. An important policy implication emerging from this study is to facilitate the establishment of financial institutions to increase credit delivery to the private sector so as to enhance private investment.

João, Barroso and Gonzalez (2017) estimated the impact of reserve requirements (RR) on credit supply in Brazil exploring a large loan-level dataset. The authors used a difference-in-difference strategy, first in a long panel, then in a cross-section. In the first case, they estimate the average effect on credit supply of several changes in RR from 2008 to 2015 using a macro prudential policy index. In the second, they use the bank-specific regulatory change to estimate credit supply responses from (I) a countercyclical easing policy implemented to alleviate a credit crunch in the aftermath of the 2008 global crisis; and (2) from its related tightening, findings show evidence of a lending channel where more liquid banks mitigate RR policy. Exploring the two phases of countercyclical policy, they found that the easing impacted the lending channel on average two times more than the tightening. Foreign and small banks mitigate these effects and banks are prone to lend less to riskier firms. 
AdeniyiI, Adeyemi, Salawudeen and Fagbemi (2018) investigated the relationship that exists between monetary policy instruments and Deposit Money Banks Loans and Advances in Nigeria. Annual time series data covering a period from I98I2016 were used and the Toda and Yamamoto granger non-causality model was employ to examine the relationship existing between Deposit Money Banks loan and advances and monetary policy variables in Nigeria. Findings revealed that structural changes in monetary policy system exerted positive significant impact on loan and advances of Deposit Money Banks in Nigeria. Findings also revealed bidirectional relationship existing between MPR and loan and advances of Deposit Money Banks in Nigeria. Precisely, MPR proved to be a significant variable which causes Deposit Money Bank loans and advances in Nigeria. Other explanatory variables (broad money supply, liquidity ratio, inflation rate and cash reserve ratio does not granger cause loan and advances of Deposit Money Banks in Nigeria within the study period. It concluded that the structural change in monetary policy system and monetary policy rate have significant impact on loan and advances of deposit money banks in Nigeria.

Ogolo (2018) empirically examined the effects of monetary policy on commercial banks' lending to the real sector from I98I2014 using multiple regression models aided by Software Package for Social Sciences. The study modeled commercial banks credit to agricultural and manufacturing sector as the function of interest rate, monetary policy rate, treasury bill rate, exchange rate, broad money supply and liquidity ratio. The regression results from model one found that interest rate, monetary policy rate have positive relationship with commercial banks' lending to the agricultural sector while Treasury bill rate, exchange rate, broad money supply and liquidity ratio have negative effect on the dependent variable. Model two found that interest rate, Treasury bill rate, exchange rate, broad money supply and liquidity ratio have negative effect on commercial banks' lending to the manufacturing sector while monetary policy rate have positive relationship with the dependent variable.

Courage and Leonard (2019) examined the effect of commercial bank sectorial credit to the manufacturing and agricultural subsectors on economic growth in Nigeria with time series data from I98I to 2015, using co-integration and error correction mechanism. The study specifies a three equation model to analyze the variables which include; real GDP, bank sectorial credit to manufacturing and agriculture subsectors, monetary policy rate, financial market development, sourced from CBN statistical bulletin and also the interaction variables, Empirical result revealed that commercial bank credit to the manufacturing and agricultural subsectors significantly affects economic growth in Nigeria both in the short run and in the long run. Furthermore, development of the financial sector enhances the growth effects of commercial banks credit to the manufacturing and agricultural subsectors of the economy.

UbesieI, Echekoba, Chris-Ejiogu and Ananwude (2019) studied the effect of sectoral allocation of deposit money banks' credit on the growth of the Nigerian real economy from 2008QI to 2017Q4 using the Ordinary Least Square (OLS) regression technique. Result of the analysis revealed that deposit money banks' credit to agriculture, industries, building and construction and wholesale \& retail trade have no significant effect on agricultural, industrial, building and construction and wholesale \& retail trade contribution to real gross domestic product. Deposit money banks should remove the disparagement that the agricultural sector is not viable, and lend to farmers with genuine needs for funds at a low interest rate. The Central Bank of Nigeria can equally play a critical role in reducing the interest rate charged by deposit money banks in extending credit to the economy by cutting down the monetary policy rate to a single digit compared to the current double digit of I4\%.

Olorunmade, Samuel, and Adewole, (2019) examined the determinant of private sector credit and its implication on economic growth in Nigeria. The fluctuation in the supply of money and credit is the basic causal factor at work in cyclical process; when money supply falls, prices decrease, profit decrease, production activities become sluggish and production falls and when money supply expands, price rise, profit increase and the total output increases and finally growth takes place.Sample regression analysis were used to analyse data obtained from Central Bank of Nigeria statistical bulletin from 2000 to 2017 . It was revealed in the determinant of credit supply that there was significant relationship between Total credits to private sector and money supply in Nigeria. The study also finds that there was significant relationship between private sector credit and economic growth in Nigeria.

\section{Literature Gap}

Dhanuskodi (2014) examines the impact of Loan Deposit ratio on the profitability of Malaysian commercial banks for the period of 2009 to 2013 using all the 8 locally owned commercial banks in Malaysia. Gap and Focus of Present Study: The above study is a foreign study and does not capture the effect of DMBs monetary policy on private sector funding. The study only captures the impact of monetary policy instrument (LDR) on banks profitability. The present study will be carried out in Nigeria and focus on the effect of DMBs policy on private sector funding. Daniel (2017) examined the evidence of the impact of liquidity management on the performance of deposit money banks. 24 banks were surveyed which constitute the entire deposit money banking industry in Nigeria between 1986 and 20II. Secondary data were collected and analyzed using SPSS. Gap and Focus of Present Study: The above though carried out in Nigeria; it does not capture the impact of DMBs monetary 
policy on private sector funding. The study only examined the effect of liquidity management on the performance of deposit money banks. This present study empirically focused on the effect of deposits money banks policy on private sector funding in Nigeria.

\section{Methodology}

This study used ex-post facto quasi-experimental research design to examine the effect of deposit money banks policy on private sector funding in Nigeria. This study employed secondary data sourced mainly from the Central Bank of Nigeria (CBN) statistical bulletin from 1985 to 2018.

\section{Model Specification}

The study models are specified below:

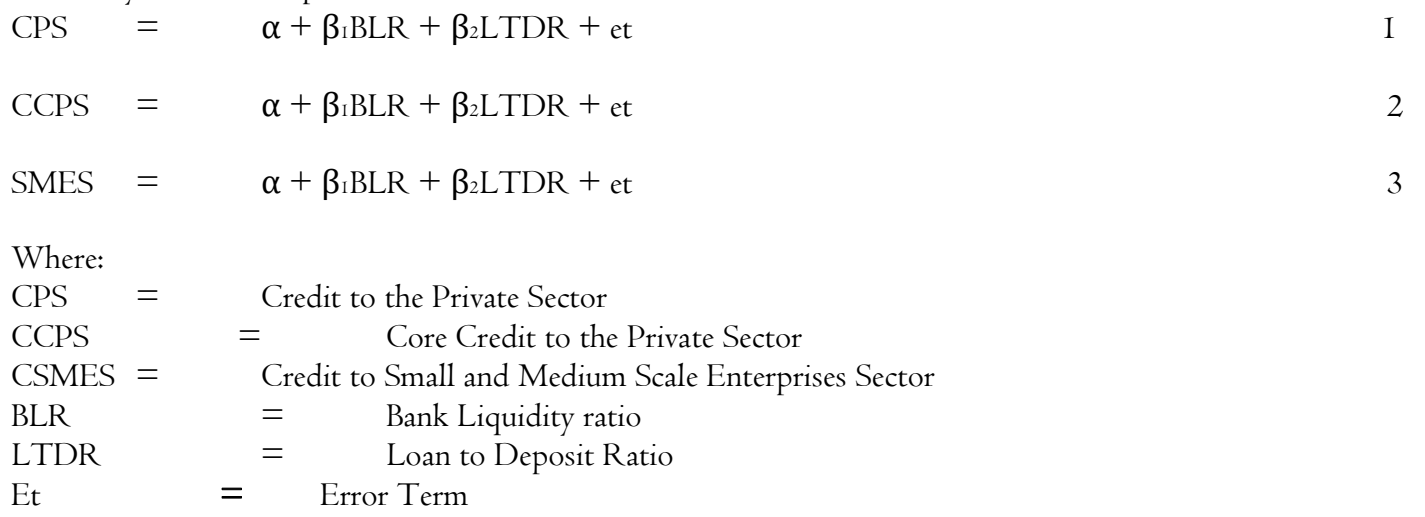

\section{Techniques of Data Analysis}

The main tool of analysis is the Ordinary Least Squares (OLS) using the multiple regression method for a period of 34 years, annual data covering 1985- 2018. Statistical evaluation of the global utility of the analytical model, so as to determine the reliability of the results obtained were carried out using the coefficient of correlation ( $r$ ) of the regression, the coefficient of determination $\left(\mathrm{r}^{2}\right)$, the student $\mathrm{T}$-test and F-test.

(i) Coefficient of Determination $\left(\mathbf{r}^{2}\right)$ Test: This measure the explanatory power of the independent variables on the dependent variables. $R^{2}$ gives the proportion or percentage of the total variation in the dependent variable $Y$ that is accounted for by the single explanatory variable $\mathrm{X}$. The higher the $\mathrm{R}^{2}$ value the better. For example, to determine the proportion of monetary policy to private sector funding in our model, we used the coefficient of determination. The coefficient of determination varies between 0.0 and I.O. A coefficient of determination says 0.20 means that $20 \%$ of changes in the dependent variable are explained by the independent variable $(\mathrm{s})$. Therefore, we shall use the $\mathrm{R}^{2}$ to determine the extent to which variation in DMBs policy variables are explained by variations in private sector funding variables over the periods covered in this study.

(ii) Correlation Co-Efficient (R): This measures the degree of the relationship between two variables $x$ and $y$ in a regression equation. That is, it tries to establish the nature and magnitude of the relationship when two variables are been analyzed. Thus correlation co-efficient show whether two variables are positively or negatively correlated. That is, it takes the value ranging from $-\mathrm{I}$, to $+\mathrm{I}$.

(iii) F-Test: This measures the overall significance. The extent to which the statistic of the coefficient of determination is statistically significant is measured by the F-test. The F-test can be done using the F-statistic or by the probability estimate. We use the F-statistic estimate for this analysis.

(iv) Student T-test: measures the individual statistical significance of the estimated independent variables. This is a test of significance used to test the significance of regression coefficients (Gujurati, 2003). Generally speaking, the test of significance approach is one of the methods used to test statistical hypothesis. A test of significance is a procedure by sample results are used to verify the truth or falsity of a null hypothesis (Ho) at 5\% level of significance. 
(v) Durbin Watson Statistics: This measures the collinearity and autocorrelation between the variables in the time series. It is expected that a ratio of close to 2.00 is not auto correlated while ratio above 2.00 assumed the presence of autocorrelation.

(vi) Regression coefficient: This measures the extent in which the independent variables affect the dependent variables in the study.

(vii) Probability ratio: It measures also the extent in which the independent variables can explain change to the dependent variables given a percentage level of significant.

\section{Stationarity (Unit Root) Tests}

Stationary test therefore checks for the stationarity of the variables used in the models. If stationary at level, then it is integrated of order zeroi, I(0). Thus, test for stationarity is also called test for integration. It is also called unit root test. Stationarity denotes the non-existence of unit root. We shall therefore subject all the variables to unit root test using the augmented Dickey Fuller (ADF) test specified in Gujarati (2004) as follows.

$$
\Delta y_{t}=\beta_{1}+\beta_{2}+\delta y_{t-1}+\alpha i \sum_{i-1}^{m} \Delta y_{t-1}+E t
$$

Where:

$$
\begin{array}{lll}
\Delta y_{t} & = & \text { change time t } \\
\Delta y_{t-1} & = & \text { the lagged value of the dependent variables } \\
\sum_{t} & = & \text { White noise error term }
\end{array}
$$

If in the above $\delta=0$, then we conclude that there is a unit root. Otherwise there is no unit root, meaning that it is stationary. The choice of lag will be determined by Akaike information criteria.

\section{Co-integration Test (The Johansen' Test)}

It has already been warned that the regression of a non-stationary time series on another non stationary time series may lead to a spurious regression. If the residual is found to be stationary at level, we conclude that the variables are co-integrated and as such has long-run relationship exists among them.

$$
\begin{aligned}
& C P S_{t}=w_{O}+\sum_{i=1}^{i} \vartheta_{t} C P S_{t-i}+\sum_{i=1}^{j} \varpi_{i} C P S_{j t-i}+\mu_{1 t} \\
& C C P S_{t}=w_{O}+\sum_{i=1}^{i} \vartheta_{t} C C P S_{t-i}+\sum_{i=1}^{j} \varpi_{i} C C P S_{j t-i}+\mu_{1 t} \\
& S M E s_{t}=w_{O}+\sum_{i=1}^{i} \vartheta_{t} S M E s_{t-i}+\sum_{i=1}^{j} \varpi_{i} S M E s_{j t-i}+\mu_{1 t}
\end{aligned}
$$

Granger Causality Test

Causality means the impact of one variable on another, in other-words; causality is when an independent variable causes changes in a dependent variable. The pair-wise granger causality test is mathematically expressed as:

$$
\begin{aligned}
& Y_{t} \pi_{o}+\sum_{i=1}^{n} x_{1}^{y} Y_{t-1} \sum_{i=1}^{n} \pi_{1}^{x} x_{t-1}+u_{1} \\
& \text { and } \\
& \mathrm{x}_{\mathrm{t}} \mathrm{dp}_{\mathrm{o}}+\sum_{\mathrm{i}=1}^{\mathrm{n}} \mathrm{dp}_{1}^{\mathrm{y}} \mathrm{Yt}-1 \sum_{\mathrm{i}=1}^{\mathrm{n}} \mathrm{dp} 1^{\mathrm{x}} \mathrm{x}_{\mathrm{y}-1}+\mathrm{V}_{1}
\end{aligned}
$$


Where $x_{t}$ and $y_{t}$ are the variables to be tested white $u_{t}$ and $v_{t}$ are the white noise disturbance terms. The null hypothesis $\pi_{1}^{y}=d p_{1}^{y}=0$, for all I's is tested against the alternative hypothesis $\pi_{1}^{x} \neq 0$ and $d p_{1}^{y} \neq 0$. if the co-efficient of $\pi_{1}^{x}$ are statistically significant but that of $d p l y$ are not, then $x$ causes $y$. If the reverse is true then y causes x. however, where both co-efficient of $\pi_{1}^{x}$ and $d p_{1}^{y}$ are significant then causality is bi-directional.

\section{Vector Error Correction (VEC) Technique}

The presence of co-integrating relationship forms the basis of the use of Vector Error Correction Model. E-views econometric software is used for data analysis, implement vector Auto-regression (VAR)- based co-integration tests using the methodology developed by Johansen (I99I,I995). The non-standard critical values are taken from (Osterward, I992).

4. Results and Discussion of Findings

Table I: Short Term Regression Results

\begin{tabular}{|c|c|c|c|c|c|c|c|}
\hline \multicolumn{3}{|c|}{ DMBs Policy and Credit To Private Sector } & \multicolumn{5}{|c|}{ DMBs Policy and Credit To Core Private Sector } \\
\hline Variable & Coefficient & t-test & Prob. & Variable & Coefficient & t-test & Prob. \\
\hline LTDR & $-0.067 \mathrm{II} 2$ & $-0.92754 \mathrm{I}$ & 0.3608 & LTDR & $0.05838 \mathrm{I}$ & I.6I333I & 0.II7I \\
\hline BLR & -0.395088 & $-\mathrm{I} .7 \mathrm{I} 3754$ & 0.0966 & BLR & -0.077273 & -0.677874 & 0.5030 \\
\hline $\mathrm{C}$ & 23.33372 & 3.595452 & $0.001 \mathrm{I}$ & $\mathrm{C}$ & 5.842477 & 1.662310 & 0.1069 \\
\hline $\mathrm{R}^{2}$ & 0.109700 & & & $\mathrm{R}^{2}$ & 0.811046 & & \\
\hline Adj R2 & $0.05226 \mathrm{I}$ & & & Adj R2 & 0.792150 & & \\
\hline F-Stat & I.909860 & & & F-Stat & 42.92288 & & \\
\hline F-Prob & 0.165126 & & & F-Prob & 0.000000 & & \\
\hline DW & 0.218049 & & & DW & 0.557335 & & \\
\hline
\end{tabular}

Source: Extract from E-view 9.0

The results of the short-run estimation are presented in table I above along with the corresponding diagnostic tests in tables below. To find out how well the model fits a set of observations, the $\mathrm{R}^{2}$ indicates that $\mathrm{I} 0$ percent and $8 \mathrm{I}$ percent of the variation in credit to private sector and core credit to the private sector is explained within the model. Nonetheless, the $\mathrm{R}^{2}$ cannot determine whether the coefficient estimates and predictions are biased, hence further assessment of the residuals is necessary. From the results it could also be deduced that loan to deposit ratio and bank liquidity ratio have negative effect on credit to private sector. Furthermore, from the results it could be deduced that loan to deposit ratio has positive effect while bank liquidity ratio has negative effect on credit to core credit to private sector.

Table 2: Unit Root Test

\begin{tabular}{ccclllll}
\multicolumn{2}{l}{$\begin{array}{c}\text { DMBs Policy and Credit To Private Sector } \\
\text { Variable }\end{array}$} & ADF & $5 \%$ & Prob. & \multicolumn{3}{l}{ DMBs Policy and Credit To Core Private Sector } \\
CPS & -4.639432 & $-2.9604 \mathrm{II}$ & 0.0000 & CCPS & -9.705692 & $-2.9604 \mathrm{II}$ & 0.0000 \\
LTDR & $-4.2 \mathrm{I} 6364$ & $-2.95402 \mathrm{I}$ & 0.0000 & LTDR & $-4.2 \mathrm{I} 6364$ & $-2.95402 \mathrm{I}$ & 0.0000 \\
BLR & -7.235884 & -2.967767 & 0.0000 & BLR & -7.235884 & -2.967767 & 0.0000 \\
\hline
\end{tabular}

Source: Extract from E-view 9.0 (2020)

The time series properties of the variables used in the analysis was investigated using Augmented Dickey-Fuller test. The test was run with specification of trend and intercept in the model. The ADF statistics for the test are presented in the table 2 above. It can be seen from the table above that the unit root test results, using the ADF unit root test suggest that all series are stationary at order I (I) because they become stationary after being differenced once. Therefore, the Engle and Granger (I987) can be employed.

Table 3: Co-integration Test

\begin{tabular}{|c|c|c|c|c|c|c|c|c|c|}
\hline $\begin{array}{l}\text { Hypothesized } \\
\text { No. of CE(s) }\end{array}$ & Eigenvalue & $\begin{array}{c}\text { Trace } \\
\text { Statistic }\end{array}$ & $\begin{array}{c}0.05 \\
\text { Critical }\end{array}$ & Prob. & $\begin{array}{l}\text { Hypothesized } \\
\text { No. of } \mathrm{CE}(\mathrm{s})\end{array}$ & Eigenvalue & $\begin{array}{c}\text { Trace } \\
\text { Statistic }\end{array}$ & $\begin{array}{c}0.05 \\
\text { Critical }\end{array}$ & Prob. \\
\hline
\end{tabular}




\begin{tabular}{cccccccccc}
\hline \multicolumn{1}{c}{ DMBs Policy and Credit To Private Sector } & \multicolumn{7}{c}{ DMBs Policy and Credit To Core Private Sector } \\
None * & 0.543161 & 25.06957 & 21.13162 & 0.0132 & None & 0.719047 & 79.69140 & 47.85613 & 0.0000 \\
At most I & 0.319038 & 12.29597 & 14.26460 & 0.1000 & At most I * & 0.576459 & 39.06521 & 29.79707 & 0.0032 \\
At most 2 & 0.034507 & 1.123715 & 3.841466 & 0.2891 & At most 2 & 0.288596 & I1.57389 & I5.4947I & 0.1785 \\
\hline
\end{tabular}

Source: Extract from E-view 9.0

From table 3 above the results of the Johansen co-integration test show that we adopt the null hypotheses of no co-integrating equation at the $5 \%$ level of significance. This implies that, there is no linear combination of the variables that are stationary in the long run and also confirms the existence of a long-run relationship between monetary policy variables and credit to private sector and credit to core private sector.

Table 4: Error Correction Model

\begin{tabular}{|c|c|c|c|c|c|c|c|}
\hline \multicolumn{4}{|c|}{ DMBs Policy and Credit To Private Sector } & \multicolumn{4}{|c|}{ DMBs Policy and Credit To Core Private Sector } \\
\hline Variable & Coefficient & t-test & Prob. & Variable & Coefficient & t-test & Prob. \\
\hline $\mathrm{C}$ & 0.564197 & 1.407637 & 0.1754 & $\mathrm{D}(\mathrm{CCPS}(-\mathrm{I}))$ & 0.131719 & 1.275962 & 0.2202 \\
\hline $\mathrm{D}(\mathrm{CPS}(-\mathrm{I}))$ & 0.279625 & I.206350 & 0.2425 & $\mathrm{D}(\mathrm{CCPS}(-2))$ & $0.14802 \mathrm{I}$ & 0.262307 & 0.7964 \\
\hline $\mathrm{D}(\mathrm{CPS}(-2))$ & -0.415204 & $-\mathrm{I} .849 \mathrm{I} 44$ & $0.080 \mathrm{I}$ & $\mathrm{D}(\operatorname{CCPS}(-3))$ & -0.764760 & 0.335028 & 0.7420 \\
\hline $\mathrm{D}(\mathrm{CPS}(-3))$ & -0.057267 & $-0.24283 \mathrm{I}$ & 0.8107 & $\mathrm{D}(\operatorname{LTDR}(-\mathrm{I}))$ & -0.033402 & -1.360830 & 0.1924 \\
\hline $\mathrm{D}(\operatorname{LTDR}(-\mathrm{I}))$ & 0.011215 & 0.310737 & 0.7594 & $\mathrm{D}(\operatorname{LTDR}(-2))$ & 0.071733 & -0.657523 & 0.5202 \\
\hline $\mathrm{D}(\operatorname{LTDR}(-2))$ & 0.009938 & 0.294156 & 0.7718 & $\mathrm{D}(\operatorname{LTDR}(-3))$ & $0.00154 \mathrm{I}$ & I.49I720 & 0.1552 \\
\hline $\mathrm{D}(\operatorname{LTDR}(-3))$ & 0.078231 & 2.279508 & 0.0344 & $\mathrm{D}(\mathrm{BLR}(-\mathrm{I}))$ & -0.094156 & 0.028357 & 0.9777 \\
\hline $\mathrm{D}(\mathrm{BLR}(-\mathrm{I}))$ & 0.049728 & 0.468390 & 0.6448 & $\mathrm{D}(\mathrm{BLR}(-2))$ & 0.055822 & -0.690108 & 0.5000 \\
\hline $\mathrm{D}(\mathrm{BLR}(-2))$ & -0.124536 & $-\mathrm{I} .172818$ & 0.2554 & $\mathrm{D}(\operatorname{BLR}(-3))$ & -0.076869 & 0.353759 & $0.728 \mathrm{I}$ \\
\hline $\mathrm{D}(\mathrm{BLR}(-3))$ & -0.034666 & -0.355103 & 0.7264 & $\operatorname{ECM}(-\mathrm{I})$ & $0.3799 \mathrm{I} 4$ & -0.576592 & 0.5722 \\
\hline ECM(-I) & $-0.03 \mathrm{I} 462$ & -0.385968 & 0.7038 & & & & \\
\hline $\mathrm{R}^{2}$ & 0.408549 & & & $\mathrm{R}^{2}$ & 0.281129 & & \\
\hline $\operatorname{Adj} R^{2}$ & 0.097260 & & & Adj $R^{2}$ & 0.102954 & & \\
\hline F-Stat & I. 312440 & & & F-Stat & 0.481317 & & \\
\hline F-prob & $0.292 \mathrm{I} 24$ & & & F-prob & 0.905265 & & \\
\hline DW & I.757685 & & & DW & 2.025376 & & \\
\hline
\end{tabular}

Source: Extract from E-view 9.0

The corresponding sign of Error Correction Term (ECT) is negative for the models but not significant. This means that there is a long run causality running from independent variables to the dependent variable. The negative sign of (ECT) indicates a move back towards equilibrium following a shock to the system in the previous year. The $\mathrm{R}^{2}$ from the models proved that the independent variables can explain 40 and 28 percent changes on the dependent variables. The models are statistically not significant from the value of $\mathrm{f}$-statistics and probability. However, the ECM coefficient indicates that the models can adjust at the speed of 3 and 37 percent annually. The coefficient of the variables defines the effect of the independent variables on the dependent variables at various lags.

Table 5: Granger Causality Test

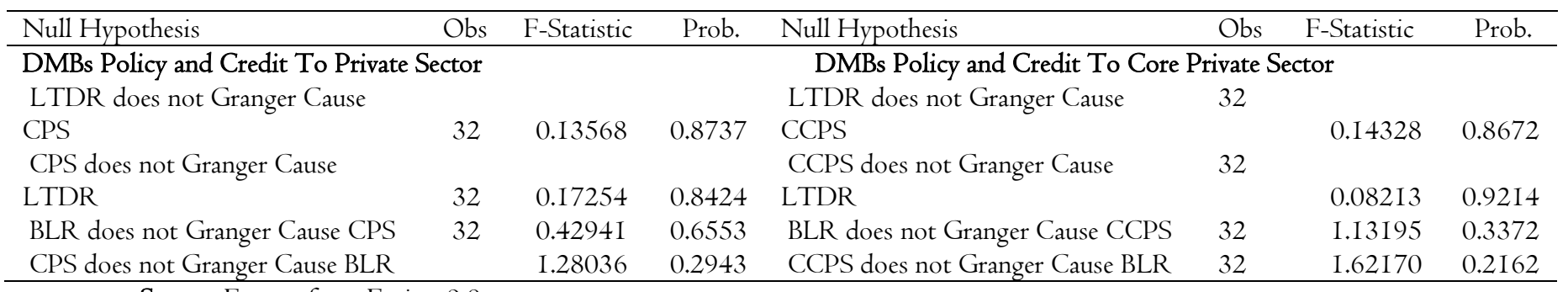

Source: Extract from E-view 9.0 
Pair wise causality tests were run on the models with an optimal lag of 2 . The results are presented in table 5 above. The researcher's interest here is to establish the direction of causality between the independent variables and the dependent variables from 1985-2018. The models shows that there is no causality running from the dependent variables to independent variables and vice versa.

Table 6: Short Term Regression Results

\begin{tabular}{crrr}
\hline \multirow{2}{*}{ Variable } & $\begin{array}{c}\text { Deposit Money Banks Policy and Credit to Small and Medium Scale Enterprises Sector } \\
\text { Coefficient }\end{array}$ & t-test & Prob. \\
\hline LTDR & $-0.1 \mathrm{I} 8892$ & $-\mathrm{I} .268007$ & $0.2 \mathrm{I} 45$ \\
BLR & 0.770832 & $2.8 \mathrm{I} 3736$ & 0.0086 \\
C & -1.099937 & -0.133762 & 0.8945 \\
R $^{2}$ & $0.24 \mathrm{I} 69 \mathrm{I}$ & & \\
Adj R2 & 0.191137 & \\
F-Stat & 4.780853 & \\
F-Prob & 0.015765 & & \\
& & & \\
DW & $0.52546 \mathrm{I}$ & &
\end{tabular}

Source: Extract from E-view 9.0

The results of the short-run estimation are presented in table 5 above along with the corresponding diagnostic tests in tables below. To find out how well the model fits a set of observations, the $\mathrm{R}^{2}$ indicates that 24.I percent of the variation in $\mathrm{DMBs}$ funding to small and medium scale enterprises sector is explained within the model. Nonetheless, the $\mathrm{R}^{2}$ cannot determine whether the coefficient estimates and predictions are biased, hence further assessment of the residuals necessary. From the result it could be deduced that loan to deposit ratio has negative effect while bank liquidity ratio has positive effect on credit to small and medium scale enterprises sector.

Table 7: Unit Root Test

\begin{tabular}{llll}
\hline & Deposit Money Banks Policy and Credit to Small and Medium Scale Enterprises Sector & \\
Variable & ADF & $5 \%$ & 0.0000 \\
\hline SMEs & -5.921945 & -2.976263 & 0.0007 \\
LTDR & -4.739563 & -2.967767 & 0.0023 \\
BLR & -4.216364 & -2.954021 & \\
\hline
\end{tabular}

Source: Extract from E-view 9.0

The time series properties of the variables used in the analysis was investigated using Augmented Dickey-Fuller test. The test was run with specification of trend and intercept in the model. The ADF statistics for the test are presented in the table above. It can be seen from the table above that the unit root test results, using the ADF unit root test suggest that all series are I (I) because they become stationary after being differenced once. Therefore, the Engle and Granger (I987) can be employed.

Table 8: Co-integration Test

\begin{tabular}{ccccc}
\hline $\begin{array}{c}\text { Hypothesized } \\
\text { No. of CE }(\mathrm{s})\end{array}$ & Eigenvalue & $\begin{array}{c}\text { Trace } \\
\text { Statistic }\end{array}$ & $\begin{array}{l}0.05 \\
\text { Critical Value }\end{array}$ & Prob. \\
\hline None & & $37.6284 \mathrm{I}$ & 29.79707 & $0.005 \mathrm{I}$ \\
At most I & 0.496177 & 17.06252 & $\mathrm{I} 5.4947 \mathrm{I}$ & 0.0288 \\
At most 2 & 0.361479 & 3.604479 & 3.841466 & 0.0576 \\
\end{tabular}

Source: Extract from E-view 9.0

From table 8, the results of the Johansen co-integration test show that we adopt the null hypotheses of no co-integrating equation at the $5 \%$ level of significance. This implies that, there is no linear combination of the variables that are stationary in the long run and also confirms the existence of a long-run relationship between DMBs policy variables and credit to small and medium scale enterprises sector in Nigeria. 
Table 9: Error Correction Model

Deposit Money Banks Policy and Credit to Small and Medium Scale Enterprises Sector

\begin{tabular}{|c|c|c|c|}
\hline Variable & Coefficient & t-test & Prob. \\
\hline $\mathrm{C}$ & -I7.29070 & $0.02274 \mathrm{I}$ & 0.9822 \\
\hline $\mathrm{D}(\operatorname{SMES}(-\mathrm{I}))$ & -0.043787 & $2.963 \mathrm{I} 48$ & 0.0110 \\
\hline $\mathrm{D}(\operatorname{SMES}(-2))$ & -0.139630 & 2.I I 4837 & 0.0543 \\
\hline $\mathrm{D}(\operatorname{SMES}(-3))$ & -0.285653 & $2.2332 \mathrm{I} 4$ & 0.0437 \\
\hline $\mathrm{D}(\operatorname{LTDR}(-\mathrm{I}))$ & -0.020892 & $2.5 \mathrm{I} 26 \mathrm{II}$ & 0.0260 \\
\hline $\mathrm{D}(\operatorname{LTDR}(-2))$ & 0.208784 & $-\mathrm{I} .58 \mathrm{II} 28$ & 0.1379 \\
\hline $\mathrm{D}(\operatorname{LTDR}(-3))$ & -0.038395 & -2.065428 & 0.0594 \\
\hline $\mathrm{D}(\operatorname{BLR}(-\mathrm{I}))$ & -0.410439 & I.I2I600 & 0.2823 \\
\hline $\operatorname{BLR}(-2)$ & 0.108664 & 3.350254 & 0.0052 \\
\hline $\operatorname{BLR}(-3)$ & 0.805284 & 2.700478 & 0.0182 \\
\hline $\operatorname{ECM}(-\mathrm{I})$ & $-0.42868 \mathrm{I}$ & 0.618165 & $0.547 \mathrm{I}$ \\
\hline $\mathrm{R}^{2}$ & 0.589935 & & \\
\hline $\operatorname{Adj} R^{2}$ & $0.34872 \mathrm{I}$ & & \\
\hline F-Stat & 2.445688 & & \\
\hline F-prob & 0.050320 & & \\
\hline DW & I.580857 & & \\
\hline
\end{tabular}

Source: Extract from E-view 9.0

The corresponding sign of Error Correction Term (ECT) is negative but not significant. This means that there is a long run causality running from independent variables to the dependent variable. The negative sign of (ECT) indicates a move back towards equilibrium following a shock to the system in the previous year. The $\mathrm{R}^{2}$ from the model proved that the variables can explain 58.9 percent changes on the dependent variables. The models are statistically significant from the value of $\mathrm{f}$-statistics and probability. However, the ECM coefficient indicates that the models can adjust at the speed of 42.8 percent annually. The coefficient of the variables defines the effect of the independent variables on the dependent variables at various lags.

\section{Table I0: Granger Causality Test}

\begin{tabular}{|c|c|c|c|}
\hline Null Hypothesis & Obs & F-Statistic & Prob. \\
\hline LTDR does not Granger Cause SMES & 32 & 0.96925 & 0.3932 \\
\hline SMES does not Granger Cause LTDR & 32 & $\mathrm{I} .7 \mathrm{I} 470$ & 0.2005 \\
\hline BLR does not Granger Cause SMES & 32 & I.43567 & 0.2569 \\
\hline SMES does not Granger Cause BLR & 32 & 0.86750 & 0.4323 \\
\hline
\end{tabular}

\section{Source: Extract from E-view 9.0}

Pair wise causality tests were run on the models with an optimal lag of 2 . The results are presented in table I0 above. The researcher's interest here is to establish the direction of causality between the dependent variables and the independent variables from 1985-2018. The models shows that there is no causality from the dependent variables to independent variables and vice versa.

\section{Discussion of findings}

In model I, the estimated regression model from result of the vector error correction result in table 4 the relationship between deposit money bank rates policy and credit to private sector is moderate and not significant. This is because of an $\mathrm{R}^{2}$ of 0.408549 meaning that the model explains approximately 40.8 percent of the total variations in the credit to private sector. The error correction model shows a negative value of -0.03 I462 which is appropriate and is significant. This means that 3 percent of the deviation from long run equilibrium relationship in the credit to private sector is corrected every year since credit to private sector is estimated annually. Some of the values of the coefficient of independent variables, that is deposit money bank policy rates are positive and also proved negative at various lags.

The negative findings of the study confirm the findings of Ogolo (2019) who found that interest rate, Treasury bill rate, exchange rate, broad money supply and liquidity ratio have negative effect on commercial banks' lending to the manufacturing 
sector. Ajayi and Atanda (2012) that liquidity ratio and cash reserve ratio exert negative impact on banks total credit and Jegede (20I4) who finds that liquidity ratio and money supply exert negative effect on commercial bank's loans and advances. Daniel (20I7) opine that the correlation results reveal positive impacts between return on equity and liquidity management variables: liquidity and cash reserve ratios, whereas loan to deposit ratio shows negative impact. Also, Alphonce, et al. (2015) opine that the negative impact implies that an inverse relationship exists between the ratio of loans to deposits and a bank's profitability.

From Model 2, the estimated regression model from result of the vector error correction model in table 4 the relationship between deposit money bank policy rates and credit to core private sector is moderate and not significant. This is because of an $\mathrm{R}^{2}$ of 0.28I 129 meaning that the model explains approximately 28.I percent of the total variations in the credit to core private sector. The error correction model shows a positive value of 0.3799I4 which is appropriate and is significant. This means that 37 percent of the deviation from long run equilibrium relationship in the credit to core private sector is corrected every year since credit to core private sector is estimated annually. Some of the values of the coefficient of independent variables that is DMBs policy rates are positive and also proved negative at various lags.

The positive findings confirm the findings of Dhanuskodi (20I5) that there was a positive and non-significant impact of LDR on ROA in five banks out of the 8 studied banks. It also confirms the findings of Atemnkenf and Josep (2006), cited in Husain and Abdullah (2008), whose findings illustrated a positive correlation between the loan to deposit ratio and bank's profitability. Conversely, Daniel (2017) opine that the correlation results reveal positive impacts between return on equity and liquidity management variables (liquidity and cash reserve ratios). The positive findings of the study also confirm the findings of Anigbogu, Okoli and Nwakoby (2015) that with the exception of bank interest rate to SMEs, all other variables namely bank lending rate to SMEs, exchange rate and monetary policy have a positive and significant influence on small and medium enterprises performance in Nigeria. Dada (20I4) opines that commercial banks credit to SMEs and the saving and time deposit of commercial banks exert a positive and significant influence on SMEs and Suleyman (2013) that money supply has a strong effect for manufacturing sector credit volume.

The negative findings of the study confirm the findings of Ajayi and Atanda (2012) that liquidity ratio and cash reserve ratio exert negative impact on banks total credit and Jegede (20I4) who finds that liquidity ratio and money supply exert negative effect on commercial bank's loans and advances.

In model 3, it is evidence that the estimated regression model from result of the vector error correction result in table 9 that the relationship between deposit money banks policy rate and credit to small and medium scale enterprises sector is high and significant. This is because of an $\mathrm{R}^{2}$ of 0.589935 meaning that the model explains approximately 58.9 percent of the total variations in the credit to small and medium scale enterprises sector. It is also evidence that the error correction model shows a negative value of - $0.42868 \mathrm{I}$ which is appropriate and is significant. This means that 42 percent of the deviation from long run equilibrium relationship in the credit to small and medium scale enterprises sector is corrected every year since credit to small and medium scale enterprises sector is estimated annually. Some of the values of the coefficient of independent variables, that is deposit money bank policy rates are positive and also proved negative at various lags.

The positive effect of the variables as shown confirm the a-priori expectation of the study and validates the objectives of monetary policy. The findings also confirm the findings of Akambi and Ajagbe (2012) that increase in interest rate will leads to a decrease in the lending rate while liquidity ratio and cash ratio were statistically significant to the profit of the selected banks. Van den Heuvel (20I5) that monetary policy affects bank lending through two channels, Djiogap and Ngomsi (20I2) that bank's capital to asset ratio, long-term liabilities, GDP growth and its size were statistically significant. Olokoyo (20II); Adelegan (2018) predictor variables (volume of deposits, investment portfolio, foreign exchange, and GDP) were statistically significant and portrayed a positive relationship with commercial bank lending. Malede (20I4) that these explanatory variables greatly influenced banks' lending decisions compared to deposit and cash required reserve which was insignificant. Nto et al, (2012) study finds policies on interest rate and liquidity ratio were negatively and positively significant to SMEs and recommend that CBN should stabilize the supply of credit to SMEs by strengthening policies on monetary policy instruments. The negative and positive findings confirm the study of Daniel (2017) that the empirical analysis show that there is a significant relationship between liquidity management and the performance of Deposit Money Banks in Nigeria and opine that the correlation results reveal positive impacts between return on equity and liquidity management variables: liquidity and cash reserve ratios, whereas loan to deposit ratio shows negative impact. Also, Alphonce, et al. (20I5) stress that the negative impact implies that an inverse relationship exists between the ratio of loans to deposits and a bank's profitability. 


\section{Conclusion}

Empirical findings proved that the $\mathrm{F}^{\star}$ - cal $=\mathrm{I} .3 \mathrm{I} 2440<\mathrm{F}^{\star}-\mathrm{tab}=2.24$ at $5 \% \mathrm{n}=3 \mathrm{I}$ is statistically not significant which is supported with a probability value of $0.292124>0.05$ at $5 \%$ is significant, we therefore reject the alternate hypothesis, that is $\beta_{\mathrm{I}}-\beta_{2}$ (deposit money bank policy rates) is statistically not significant with credit to private sector in Nigeria. Therefore, we conclude that there is no significant relationship between deposit money bank policy rates and credit to private sector in Nigeria.

It was proved that, the $\mathrm{F}^{\star}-\mathrm{cal}=0.48 \mathrm{I} 3 \mathrm{I} 7<\mathrm{F}^{*}-\mathrm{tab}=2.24$ at $5 \% \mathrm{n}=3 \mathrm{I}$ is statistically not significant which is supported with a probability value of $0.905265>0.05$ at $5 \%$ is significant, we therefore reject the alternate hypothesis, that is $\beta_{\mathrm{I}}-\beta_{2}$ (deposit money bank policy rates) is not statistically significant with credit to core private sector in Nigeria. Therefore, we conclude that there is no significant relationship between deposit money policy bank rates and credit to core private sector in Nigeria.

The study found that, the $\mathrm{F}^{*}$ - cal $=2.445688>\mathrm{F}^{*}-\mathrm{tab}=2.24$ at $5 \% \mathrm{n}=3 \mathrm{I}$ is statistically significant which is supported with a probability value of $0.050320<0.05$ at $5 \%$ is significant, we therefore reject the null hypothesis, that is $\beta_{\mathrm{I}}-\beta_{2}$ (deposit money bank policy rates) is statistically significant with credit to small and medium scale enterprises sector in Nigeria. Therefore, we conclude that there is significant relationship between deposit policy bank rates and credit to small and medium scale enterprises sector in Nigeria.

\section{Recommendations}

The study recommends compliance to deposit money banks policies, this will enhance effective financial intermediation and increase credit to private sector. There is also needs for the regulatory authorities to harmonize the various deposit money banks policies with the objective of enhancing private sector funding.

- There is need to decentralize the operation of the deposit money banks in the urban cities. Policies should be formulated to extend operation of the deposit money banks to the rural communities, this will enable the financial institutions to mobilize the much needed deposit and increase credit to the private sector.

- The study recommends that central bank should reduce deposit money banks policy rates. This is because changes in interest rates and bank credits may lead to changes in the real sector through investment and influence of aggregates demand.

\section{References}

Adelegan, A.E. (2018). Private domestic investment, Domestic Credit to the private sector and economic performance: Nigeria in perspective. IOSR Journal of Economics and Finance (IOSR-JEF). 9 (3), 22-3I.

Adeniyil, A.M., Adeyemi, A.K, Salawudeen O.S. \& Fagbemi, T.O. (20I8). Monetary policy and bank credit in Nigeria: A Toda-Yamamoto Approach. Acta Universitatis Danubius. I4(5), 7I8-73I.

Afonso, A, and Aubyn, M. (I997). Is There Credit Rationing in Portuguese Banking? Department of Economics, Working Paper No 6 (97).

Alper, K. (2012). An empirical study on liquidity and bank lending. Central Bank of the Republic of Turkey Merkez Bank Working Paper No. 12/04.

Amassoma, J.D., Nwosa, P.I. \& Ofere, A.F. (20II). The nexus of interest rate, deregulation lending rate and agricultural productivity in Nigeria. Current Research Journal of Economic Theory,3, (2):53-60.

Anigbogu, T. U., Okoli, I. M. \& Nwakoby, N. P. (2015). Financial intermediation and small and medium enterprises performance in Nigeria (An aggregated analysis: 1980-2013). European Scientific Journal, II(28), 257-272.

Alphonce, T.S., Silvanos C. and Ziska, F. (2015). Determinants of Commercial Bank Profitability from Prior- to PostHyperinflation: Evidence from Zimbabwe. J Economics, 6(2): I29-I39.

Arora, R.U. (2014). Access to finance: An Empirical Analysis. European Journal of Development Research, 26 (5), 7.98 -8I4.

Ayub, G. \& Seyed, A.M. (2016). The relationship between monetary policy and bank lending behavior and the influence of bank specific features on this relationship in the banks listed on the Tehran Stock Exchange. International Journal of Advanced Biotechnology and Research (IJBR), 7(2).II5-I25.

Baltensperger, E. \& Devinney, T. (I985). Credit rationing theory: A survey and synthesis. Zeitschrift für die gesamte Staatswissenschaft, I4(I), 475-502.

Berger, A. N., \& Udell, G. F. (I995). The economics of small business finance: The roles of private equity and debt markets in the financial growth cycle. Journal of Banking and Finance, 22 (6-8), 613-673.

Basle Committee on Banking Supervision (2008). Principles for Sound Liquidity Risk Management and Supervision. Basel: Bank for International Settlements. 
Bessis, J. (2009). Risk Management in Banking. Chichester: John Wiley \& Sons Inc.

Bester, H. (1985). Screening vs. rationing in credit markets with imperfect information. The American Economic Review, 75 (4), 850-855.

Bester, H., (1984a). "Screening versus Rationing in Credit Markets with Imperfect Information," Discussion Paper No. I36.

Bouvatier, López-Villavicencio and V. Mignon, 2010, "On the Link between Credit Procyclicality and Bank Competition", CEPII Working Paper, No. 20I0-25, November

Courage, O.E. \& Leonard, N.A, (2018). Impact of commercial banks' credit to the real sector on economic growth in Nigeria. Oradea Journal of Business and Economics, University of Oradea, Faculty of Economics, 4(I), 38-46.

Cressy, R. (I996). Funding gaps: A symposium. The Economic Journal, II2 (477) FI-FI6.

Daniel, B.E. (2017). Liquidity Management and Performance of Deposit Money Banks in Nigeria (I986 - $201 \mathrm{I})$ : An Investigation. International Journal of Economics, Finance and Management Sciences. 5(3), I46-I6I.

Dhanuskodi R. (2014) Impact of Loan Deposit Ratio (LDR) on Profitability: Panel Evidence from Commercial Banks in Malaysia. Proceedings of the Third International Conference on Global Business, Economics, Finance and Social Sciences (GBI4Mumbai Conference) Mumbai, India. I9-2I. Paper ID: MF498.

D'pola, K. U. and Touk, M.C. (2016). The Effect of Commercial Bank credit on the output of small and medium enterprises in Cameroon: Empirical evidence from 1980-2014. Maghreb Review of Economic Management. Vol 03 - № 02.

Eangle, R. F., \& Granger, C. W. (1987). Co- integration and Error Correction: Representation, Estimatin and Testing. Journal of Econometrican, 25I-276.

Echekoba, F.N. \&Ubesie M.C. (2018) Assessment of Financial Deepening on the Growth of Nigerian Economy: I990-20I6. International Journal of Academic Management Science Research (IJAMSR). Vol. 2 Issue I I, Pages: 70-82.

Eke, A.F., Chikulirim, E.I. and Inyang, O.G. (20I5) Interest rate and commercial banks' lending operations in Nigeria: A structural break analysis using chow test. Global Journal of Social Sciences. Vol I4, 2015: 9-22.

CGFS (2012). CGFS Working Group on the selection and application of macro-prudential instruments. (SAM), unpublished manuscript.

Gujarati, D. N. (2004). Basic econometrics (4th Ed.) McGraw-Hill, New York.

Husain A.L.O, Abdullah, A.L.M 2008. Bank specific determinants of profitability. The case of Kuwait. Journal of Economic and Administrative Sciences, 24: 20-34.

Hyunggeun P., Hyunwoo J., Dokyung, L. (20I5). Evaluation on the usefulness of the loan-to-deposit ratio regulation - From the macroprudential policy perspective. Financial Research Team, Financial Stability Department, Bank of Korea working paper.

Hossain, S. A., \& Islam, K. M. A. (2017). Impact of Basel II \& III Implementation to Mitigate Bank Risk: A Study on A1Arafah Islami Bank Limited. Indian Journal of Finance and Banking, I(2), 42-5I. https://doi.org/I0.4628I/ijfb.vIi2.88

Hossain, S. A., \& Islam, K. A. (2015). The Relationship of the Macroeconomic Variables with the Growth of Garment Industry in Bangladesh. Global Disclosure of Economics and Business, 4(I), 63-78. https://doi.org/IO.I8034/gdeb.v4iI.I53

Hossain, S. A., Islam, M. N., Mahmud, M. S., \& Islam, K. A. (2017). Evaluation of Financial Performance of Commercial Banks in Bangladesh: Comparative Study Based on CAMEL Approach. The Millennium University Journal, 2(I), 5477. Retrieved from http://www.themillenniumuniversity.edu.bd/journal/index.php/TMUJ/article/view/22

Islam, K. A. (2012). Performance Evaluation of the Banking Industry in Bangladesh: A Comparative Analysis. IOSR Journal of Business and Management (IOSRJBM),3(4),9-I9. https://doi.org/I0.9790/487X-03409I9

Islam, K. M. A., \& Zaman, M. (20I3). Job satisfaction \& bankers' turnover: a case study on Bangladesh commerce bank limited. International Journal of Business and Management Review, I(4), I-I4. Retrieved from https://www.eajournals.org/journals/international-journal-of-business-and-management-review-ijbmr/vol-I-issue4-december-2013/job-satisfaction-bankers-turnover-a-case-study-on-bangladesh-commerce-bank-limited/

Islam, K. A., Hossain, S. A., Zaman, M., \& Miajee, M. R. K. (2013). Poverty Alleviation in Bangladesh through Small and Medium Enterprise (SME) Loan: A Case Study on United Commercial Bank Limited at Gulshan Branch. Bangladesh Research Foundation Journal, 2(3), 29-43.

Islam, K. A. (2013). Examination of Profitability in Private Commercial Banks in Bangladesh: An Empirical Investigation. Bangladesh Research Foundation Journal, 2(2),29,68-83.

Islam, K. A., Alam, I., \& Hossain, S. A. (2014). Examination of profitability between Islamic banks and conventional banks in Bangladesh: A comparative study. Research in Business and Management, I(I), 78-89. https://dx.doi.org/I0.5296/rbm.vIiI.4894

Islam, K. A. (20I4). Foreign Direct Investment (FDI) in Bangladesh: Prospects and Challenges and Its Impact on Economy. Asian Business Review, 4(I), 24-36. https://doi.org/I0.18034/abr.v4iI.70 
Islam, K. A., \& Salma, U. (20I4). Customer satisfaction of Internet banking in Bangladesh: A case study on Citibank NA. Asian Journal of Applied Science and Engineering, 3(I), 5I-62. Retrieved from https://www.journals.abc.us.org/index.php/ajase/article/view/5I-62

Islam, K. A. (2014). Measurement of Capital Adequacy of AB Bank Limited. International Journal of Novel Research in Marketing Management and Economics, I(I), 24-39. Retrieved from https://www.noveltyjournals.com/journal/IJNRMME/Issue-I-September-20I4-December-20I4/0

Islam, K. A. (2015). Throughput accounting: a case study. International Journal of Finance and Banking Research, I(2), I9-23. https://doi.org/I0.I I648/j.ijfbr.20I50I02.I I

Islam, K. M., \& Hossain, S. (2015). Demutualization of Dhaka Stock Exchange: Opportunities and Challenges. International Journal of Finance and Banking Research, I(I), I-II. Retrieved from http://article.sciencepublishinggroup.com/html/I0.I I648.j.ijfbr.20I50I0I.I I.html

Islam, K. A., Alam, I., \& Al-Amin, D. M. (2015). Foreign exchange operation of private commercial banks in Bangladesh: A case study on $\mathrm{AB}$ Bank Limited. International Journal of Innovative Research and Creative Technology, I(3). Retrieved from http://www.ijirct.org/viewPaper.php?paperId=IJIRCTI20I06I

Islam, K. A., \& Salma, U. (2016). The role of private universities in higher education of Bangladesh: an empirical investigation. International Journal of Finance and Banking Research, 2(4), I2I-I28. https://doi.org/IO.II648/j.ijfbr.20I60204.II

Islam, K. A., \& Salma, U. (2016). Mobile Banking Operations and Banking Facilities to Rural People in Bangladesh. International Journal of Finance and Banking Research, 2(4), I47. https://doi.org/I0.I I648/j.ijfbr.20160204.I4

Islam, K. A. (2016). Impact of Micro-Financing on Women Empowerment in Bangladesh. The Millennium University Journal, I(I), I-I8. Retrieved from http://www.themillenniumuniversity.edu.bd/journal/index.php/TMUJ/article/view/I

Islam, K. A., \& Salma, U. (2016). The Renewable Energy and Sustainable Development: A Case Study of Bangladesh. International Journal of Finance and Banking Research, 2(4), I39-I46. https://doi.org/IO.II648/j.ijfbr.20160204.13

Islam, K. A. (2016). Rural Development Scheme: A Case Study on Islami Bank Bangladesh Limited. International Journal of Finance and Banking Research, 2(4), I29. https://doi.org/I0.I I648/j.ijfbr.20160204.I2

Islam, K. M. A. (2016). Development of Bangladesh through SMEs Financing: A Case Study on IDLC Finance Limited” Discovery, 52(250), 204I-2053. Retrieved from http://www.discoveryjournals.org/discovery/current_issue/v52/n250/A8.pdf?\#zoom=I25

Islam, K. M. A. (2016). Assessment of Customer Loyalty: A Case Study of Banglalink. Indian Journal of Science, 23(84),633668. Retrieved from https://discoveryjournals.org/science/current_issue/2016/A59.pdf

Islam, K. M. A. (20I6). Financial Performance Comparison of Top Rated Banking Financial Institutions (BFIs) of Bangladesh. Indian Journal of Science, 23(85),669-697.Retrieved from https://discoveryjournals.org/science/current_issue/2016/A60.pdf

Islam, K. M. A. (2016). Corporate Governance: Conjecture and Modernism, Indian Journal of Science,23(86), 7988I7.Retrieved from https://discoveryjournals.org/science/current_issue/20I6/A66.pdf

Islam, K. M. A. (2016). Factors Influencing Consumers Purchase Decision: A Case Study of Pantene Shampoo. Indian Journal of Science, 23(88),9I0-923.Retrieved from https://discoveryjournals.org/science/current_issue/2016/A74.pdf

Islam, K. M. A. (2016). Young Leadership and Their Contribution to Develop A New Bangladesh: A Case Study On BYLC. Indian Journal of Science, 23(88), 944-969. $\quad$ Retrieved from https://discoveryjournals.org/science/current_issue/2016/A76.pdf

Islam, K. M. A. (2016). E-Commerce: Concept and Evolution. Indian Journal of Science, 23(88), 976-983.Retrieved from https://discoveryjournals.org/science/current_issue/2016/A78.pdf

Islam, K. M. A. (2016). History and Role of Islamic Finance. Discovery, 52(252), 24I0-24I8.Retrieved from https://discoveryjournals.org/discovery/current_issue/v52/n252/A8.pdf?\#zoom=I25

Islam, K. M. A., \& Barghouthi, O. (2017). Human Resource Management: An Islamic Perspective. International Journal of Islamic Business \& Management, I(I), IO-I3. https://doi.org/I0.4628I/ijibm.vIiI.46

Islam, K. M. A., \& Barghouthi, O. A. (2017). Corporate Governance: An Islamic Institution Perspective. International Journal of Islamic Banking and Finance Research, I(I), 29-32. https://doi.org/I0.4628I/ijibfr.vIiI.36

Islam, K. A. (2017). An Empirical Research on Beximco Knitting Ltd: Ratio, DuPont, Valuation and Pro-Forma Analysis. Indian Journal of Finance and Banking, I(I), I-7. https://doi.org/I0.4628I/ijfb.vIiI.80

Islam, K. M. A. (2017). Finance: An Islamic Perspective. International Journal of Islamic Banking and Finance Research, I(I), I-5. https://doi.org/I0.4628I/ijibfr.vIiI.32

Islam, K. M. A., \& Barghouthi, O. A. (2017). An Islamic Perspective of Marketing. International Journal of Islamic Business \& Management, I(I), I7-I9. https://doi.org/I0.4628I/ijibm.vIiI.48 
Islam, K. M. A., \& Karim Miajee, M. R. (2017). An Islamic Perspective of Leadership. International Journal of Islamic Business \& Management, I(I), I4-I6. https://doi.org/I0.4628I/ijibm.vIiI.47

Islam, K. M. A., \& Barghouthi, O. A. (2017). An Islamic Perspective of Marketing. International Journal of Islamic Business \& Management, I(I), I7-I9. https://doi.org/I0.4628I/ijibm.vIiI.48

Islam, K. M. A., \& Karim Miajee, M. R. (2017). Business Ethics: An Islamic Perspective. International Journal of Islamic Business \& Management, I(I), 7-9. https://doi.org/I0.4628I/ijibm.vIiI.45

Islam, K. M. A., \& Barghouthi, O. A. (2017). Risk Management of Islamic Banking: An Islamic Perspective. International Journal of Islamic Banking and Finance Research, I(I), 25-28. https://doi.org/I0.4628I/ijibfr.vIiI.35

Islam, K. A. (2017). An Empirical Research on Fu-Wang Foods Ltd: Industry, Strategy, Accounting, Ratio, Valuation and Proforma Analysis. American Finance \& Banking Review, I(I), I-I I. https:/ /doi.org/I0.4628I/amfbr.vIiI.79

Islam, K. M. A. (2017). Performance of Foreign Exchange Operation of Private Commercial Bank: A Case on Southeast Bank Limited, Discovery, 53(254), I70-I76.Retrieved from https://discoveryjournals.org/discovery/current_issue/v53/n254/A7.pdf?\#zoom=I25

Islam, K. M. A. (2017). Predicament And Thought of SMEs Financing in Bangladesh :An Exploratory Research. Indian journal of arts, 7(22), I46-I5I.Retrieved from https://discoveryjournals.org/arts/current_issue/20I7/AI7.pdf

Islam, K. M. A. (2017). Financial Statement Analysis of Beximco Synthetics Limited. Indian Journal of Arts, 7(23), I59-I66. Retrieved from https://discoveryjournals.org/arts/current_issue/2017/AI9.pdf

Islam, K. M. A. (2017). An Empirical Research on Shinepukur Holdings Ltd: Strategy, Accounting, Ratio, Sensitivity and Prospective Analysis. Indian Journal of Arts, 7(23), I67-I74.Retrieved from https://discoveryjournals.org/arts/current_issue/2017/A20.pdf

Islam, K. M. A. (2017). The Regulatory Framework of E-Commerce. Indian Journal of Science, 24(90), 63-73. Retrieved from https://discoveryjournals.org/science/current_issue/2017/AI0.pdf

Islam, K. M. A. (2017). SMEs Financing in Bangladesh: A Case Study of Al-Arafah Islami Bank Limited. Indian Journal of Science, 24(9I), I34-I46.Retrieved from https://discoveryjournals.org/science/current_issue/2017/AI6.pdf

Islam, K. M. A. (2017). Functions and Performance Evaluation of Investment Corporation of Bangladesh (ICB): An Empirical Research. Indian Journal of Science, 24(92), 218-230.Retrieved from https://discoveryjournals.org/science/current_issue/2017/A25.pdf

Islam, K. A., \& Miajee, M. R. K. (2018). Small and Medium Enterprises (SMEs) Financing in Bangladesh: A Review of Literature. International Journal of Small and Medium Enterprises, I(I), II-I5. https://doi.org/I0.4628I/ijsmes.vIiI.62

Islam, K. M. A., \& Karim Miajee, M. R. (2018). Exploring E-Business in SMEs. International Journal of Small and Medium Enterprises, I(I), I6-I8. https://doi.org/I0.4628I/ijsmes.vIiI.63

Islam, K. M. A., \& Barghouthi, O. A. (2018). To What Extent Do the Investment Programs in the Infrastructure Sector Comply with the Determinants of National Competitive Advantage?. International Journal of Small and Medium Enterprises, I(I), 6-I0. https://doi.org/I0.4628I/ijsmes.vIiI.6I

Islam, K. M. A., \& Barghouthi, O. A. (2018). To What Extent Do the Investment Programs in the Small and Medium Enterprises Sector Comply with the Determinants of National Competitive Advantage? International Journal of Small and Medium Enterprises, I(I), I-5. https://doi.org/I0.46281/ijsmes.vIiI.60

Islam, K. A., \& Bhuiyan, A. B. (2019). The Theoretical Linkages between the Shariah Supervisory Board (SSB) and Stakeholder Theory in the Islamic Financial Institutes: An Empirical Review. International Journal of Accounting \& Finance Review, 4(2), 43-49. https://doi.org/I0.4628I/ijafr.v4i2.436

Islam, K. A. (2019). What Do the Customers Think?An Evaluation of New Products \& Services of National Bank Limited. Retrieved from https://www.cribfb.com/pdf/Thesis_20I7_0I.pdf

Jegede, C.A. (2014). Impacts of monetary policy on the commercial banks 'lending in Nigeria. Review of Public Administration and Management, 3(5), pp. I34 - I46.

Jeong, H., 2009, "The Procyclicality of Bank Lending and Its Funding Structure: The Case of Korea”, Bank of Korea International Conference on "The Credit Crisis: Theoretical Perspectives and Policy Implications", May

Jhingan, M. L. (2005). Macroeconomic theory. IOth Edition, Vrinda Publications Ltd, New Delhi

João B. R., Barroso, R. B., Gonzalez, B. F. Nazar V. D. (2017). Credit Supply Responses to Reserve Requirement: loan-level evidence from macroprudential policy. Banco Central do Brasil. Working Paper Series 467.

Johansen, S. (1988). Statistical analysis of cointegration vectors. Journal of Economics Dynamic and Control, I2, 231 - 254.

John, N.N.U. \& Onwubiko, N. D. (2013). Power of knowledge of management techniques on productivities among indigenous entrepreneurs in Nigeria. European Journal of Business Management, 5 (I2): I48-I55.

Karimo, T.M., \& Ogbonna, O.L. (2017). Financial Deepening and Economic Growth Nexus in Nigeria: Supply-Leading or Demand-Following? Economies. MPDI Articles. 
Lopez-Espinosa, G., A. Moreno, A. R., \& Valderrama, L. (2012). Short-term Wholesale Funding and Systemic Risk: A Global CoVaR Approach. IMF Working Paper, WP/I2/46, February.

Malede, M. (2014). Determinants of commercial banks' lending: evidence from Ethiopian commercial banks. European Journal of Business and Management, 2(2), 304-3I8.

Matthews, K., \& Thompson, J. (2014). The economics of banking, Wiley: Chichester, (3rd Edition).

Moore, W. (2010). How do financial crises affect commercial bank liquidity? Evidence from Latin America and the Caribbean. MPRA Paper, 21473.

Nto, P. O., Mbanasor, J. A., \& Osuala, A. E. (20I2). Influence of monetary policy variables on loan supply to small and medium scale enterprises in Nigeria. International Journal of Economics and Finance, 4(7), I57-I64.

Nwakama, and Mogbatogu., (20I4). Influence of interest rates regimes on deposit Money Banks in Nigeria: An Econometric Assessment. The Clute Institute Int'l. Academic Conference, Orlands Florida (20I4).

Odhiambo, N.M. (2010), Finance-Investment-Growth Nexus in South Africa: An ARDL-bounds Testing Procedure, Econ Change Restruct, 43, 205-219.

Ogolo, T. M. (2018). Monetary Policy and Commercial Bank Lending to the Real Sector in Nigeria: A Time Series Study. American Finance \& Banking Review, 2(I),I26-I38.

Olokoyo., (201 I). Determinants of Commercial banks' lending behavior. International Journal Financial Research, 2 (2),302316.

Olorunmade, G., Samuel, O.J., \& Adewole, J. A. (2019) Determinant of private sector credit and its implication on economic growth in Nigeria: 2000-2017. American Economic and Social Review, 5 (I), 78-90.

Olukayode, R., \& Somoye, C. (2018). The impact of finance on entrepreneurship growth in Nigeria: International Journal of Small and Medium Enterprises, I(2); II7-227.

Oshikoya, T. W., (1992). Interest rate liberalization, savings, investment and growth: The case of Kenya savings and development I6, (3): 305-320.

Osterwald-Lenum, M., (1992). A note with quantiles of the asymptotic distributions of the maximum likelihood cointegration ranks test statistics: Four Cases. Oxford Bulletin of Economics and Statistics, 54, 461-472.

Ovat, O. O. (2016). Commercial banks' credit and the growth of small and medium scale enterprises: The Nigerian experience. Journal of Economics and Finance, 7(6), 23-30.

Praet, P., Herzberg, V. (2008). Market liquidity and banking liquidity: linkages, vulnerabilities and the role of disclosure. Banque de France Financial Stability Review, 95-109.

Rychtárik, Š. (2009). Liquidity Scenario Analysis in the Luxembourg Banking Sector. BCDL Working Paper, $4 I$.

Saunders, S. (2010). Financial Markets and Institutions: An introduction to the risk management approach. McGraw Hill Pub.

Sesay, B., and Abdulai, B.S. (2017).Monetary policy effects on private sector investment: Evidence from Sierra Leone. International Journal of Economics and Financial Issues, 7(I), 476-488.

Stiglitz, J. E., \& Weiss, A. (I98I). Credit rationing in markets with imperfection. American Economic Review, 7I, (3), I6-36.

UbesieI, C.M., Echekoba, F.N., Chris-Ejiogu, U.G. and Ananwude, A.C. (2019). Sectoral Allocation of Deposit Money Banks' Credit and the Growth of Nigerian Real Economy: A Disaggregated Analysis (2008QI - 2017Q4). Journal of Economics, Management and Trade 22(I): I-22, 2019.

William, O., Zehou, S. \& Hazimi, B.H., (2019). Determinants of domestic credit to the private sector in Ghana: Application of Vector Auto Regressive Method. Advances in Social Science, Education and Humanities Research, volume 309.

\section{Copyrights}

Copyright for this article is retained by the author(s), with first publication rights granted to the journal. This is an open-access article distributed under the terms and conditions of the Creative Commons Attribution license (http://creativecommons.org/licenses/by/4.0/). 